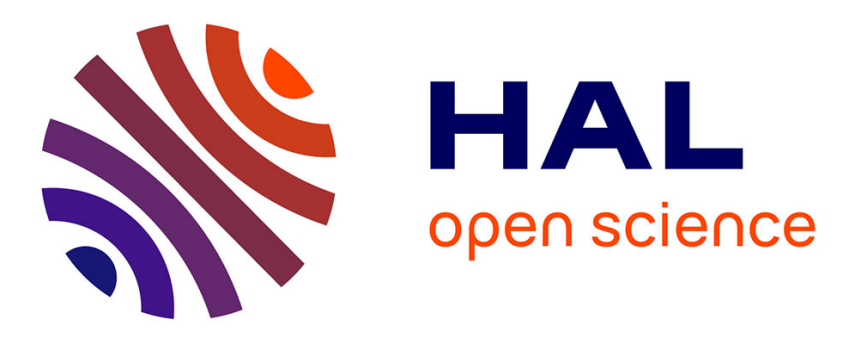

\title{
Association of ex vivo vascular and bronchial dysfunctions in smokers
}

Mehdi Oualha, Jean-François Boitiaux, Jean-Marc Tadié, Aurélie Cazes, Marc Riquet, Emmanuel Naline, Dominique Israël-Biet, Christophe Delclaux

\section{- To cite this version:}

Mehdi Oualha, Jean-François Boitiaux, Jean-Marc Tadié, Aurélie Cazes, Marc Riquet, et al.. Association of ex vivo vascular and bronchial dysfunctions in smokers. Pulmonary Pharmacology \& Therapeutics, 2011, 24 (2), pp.227. 10.1016/j.pupt.2010.12.004 . hal-00724888

\section{HAL Id: hal-00724888 \\ https://hal.science/hal-00724888}

Submitted on 23 Aug 2012

HAL is a multi-disciplinary open access archive for the deposit and dissemination of scientific research documents, whether they are published or not. The documents may come from teaching and research institutions in France or abroad, or from public or private research centers.
L'archive ouverte pluridisciplinaire $\mathbf{H A L}$, est destinée au dépôt et à la diffusion de documents scientifiques de niveau recherche, publiés ou non, émanant des établissements d'enseignement et de recherche français ou étrangers, des laboratoires publics ou privés. 


\section{Accepted Manuscript}

Title: Association of ex vivo vascular and bronchial dysfunctions in smokers

Authors: Mehdi Oualha, Jean-François Boitiaux, Jean-Marc Tadié, Aurélie Cazes, Marc Riquet, Emmanuel Naline, Dominique Israël-Biet, Christophe Delclaux

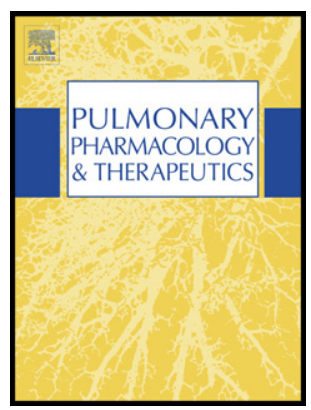

PII: $\quad$ S1094-5539(10)00146-X

DOI: $\quad$ 10.1016/j.pupt.2010.12.004

Reference: $\quad$ YPUPT 1062

To appear in: Pulmonary Pharmacology \& Therapeutics

Received Date: 15 September 2010

Revised Date: 24 November 2010

Accepted Date: 18 December 2010

Please cite this article as: Oualha M, Boitiaux J-F, Tadié J-M, Cazes A, Riquet M, Naline E, IsraëlBiet D, Delclaux C. Association of ex vivo vascular and bronchial dysfunctions in smokers, Pulmonary Pharmacology \& Therapeutics (2010), doi: 10.1016/j.pupt.2010.12.004

This is a PDF file of an unedited manuscript that has been accepted for publication. As a service to our customers we are providing this early version of the manuscript. The manuscript will undergo copyediting, typesetting, and review of the resulting proof before it is published in its final form. Please note that during the production process errors may be discovered which could affect the content, and all legal disclaimers that apply to the journal pertain. 


\section{Association of ex vivo vascular and bronchial dysfunctions}

\section{in smokers}

Mehdi Oualha ${ }^{1}$, Jean-François Boitiaux ${ }^{1 *}$, Jean-Marc Tadié ${ }^{1}$, Aurélie Cazes ${ }^{2}$, Marc Riquet ${ }^{3}$, Emmanuel Naline ${ }^{5}$, Dominique Israël-Biet ${ }^{1,4}$ and Christophe Delclaux ${ }^{1,6,7}$

* MO and JFB equally contributed to this work

${ }^{1}$ Université Paris Descartes ; UFR Biomédicale des Saints-Pères ; UPRES EA 4068 ; Paris, France

2 Assistance Publique-Hôpitaux de Paris ; Hôpital Européen Georges Pompidou ; Département d'Anatomo-Pathologie; Paris, France

${ }^{3}$ Assistance Publique-Hôpitaux de Paris ; Hôpital Européen Georges Pompidou ; Service de Chirurgie Thoracique; Paris, France

${ }^{4}$ Assistance Publique-Hôpitaux de Paris ; Hôpital Européen Georges Pompidou ; Service de Pneumologie; Paris, France

${ }^{5}$ UPRES EA 220 ; Pôle des maladies respiratoires ; Hôpital Foch, Suresnes, France

${ }^{6}$ Assistance Publique-Hôpitaux de Paris ; Hôpital Européen Georges Pompidou ; Service de Physiologie - Clinique de la Dyspnée; Paris, France

${ }^{7}$ CIC Plurithématique 9201 ; Hôpital Européen Georges Pompidou ; Paris, France

Correspondence: Dr Christophe Delclaux MD, PhD

Clinique de la Dyspnée

Hôpital Européen Georges Pompidou

20, rue Leblanc ; 75015 Paris, France

Tel : 33156093488

e-mail: christophe.delclaux@egp.aphp.fr

Short title: vascular and airway dysfunctions 


\section{Abstract}

Word count: 204

Background. It has recently been shown that systemic endothelial dysfunction is associated with airflow limitation in COPD. We conducted this ex vivo study to assess whether endothelial dysfunction of pulmonary arteries of former smokers was associated with modifications of airway functions.

Methods. Pharmacological experiments were conducted on arterial and bronchial rings obtained from lung specimen of 20 patients: 13 smokers without COPD and 7 smokers with mild to moderate COPD (GOLD class I or II). The impairment of acetylcholine-mediated vasodilation (constriction) of preconstricted arterial rings defined endothelial dysfunction. Resting tone (initial and after a contraction test) and cGMP-mediated dilation of bronchial rings in response to zaprinast were evaluated.

Results. Initial airway resting tone was correlated with airflow limitation $\left(\mathrm{FEV}_{1} \%\right.$ predicted: Rho= $-0.49 ; \mathrm{p}=0.032$ ). The acetylcholine response of arterial rings was correlated with zaprinast-induced bronchodilation $(\mathrm{Rho}=0.54, \mathrm{p}=0.019)$. Patients with endothelial dysfunction $(n=5)$, as compared with those displaying no dysfunction $(n=15)$, were characterized by an increased resting tone (after contraction test), an impaired response to zaprinast but a similar degree of airflow limitation $\left(\mathrm{FEV}_{1}\right)$.

Conclusion. Endothelial dysfunction of pulmonary arteries is associated with increased resting tone and impaired cGMP-mediated dilation of airways in former smokers, suggesting common underlying mechanisms of pulmonary arterial and bronchial dysfunctions.

Key words: zaprinast, acetylcholine, bronchial ring, arterial ring, endothelial dysfunction 


\section{Introduction}

Recent researches on the pathogenesis of chronic obstructive pulmonary disease (COPD) suggest that perturbations in the vasculature may occur early in COPD [1-3]. Nitric oxide (NO)-mediated, endothelium-dependent relaxation provoked by adenosine diphosphate and acetylcholine is attenuated in the excised pulmonary arteries of patients with COPD compared with those of smoking and non-smoking control subjects [4]. Barr and colleagues demonstrated that impaired flow-mediated dilation, assessed by brachial artery flow-mediated dilation, is associated with low pulmonary function and emphysema in ex-smokers [1]. In this latter study, a linear relationship was demonstrated between flow-mediated dilation and postbronchodilator $\mathrm{FEV}_{1}$, and the magnitude of this association was the same in former smokers who had not developed $\mathrm{COPD}\left(\mathrm{FEV}_{1} / \mathrm{FVC} \geq 70 \%\right)$ as in the overall sample (mild to severe COPD). The authors postulated that the systemic nature of endothelial function made likely the alteration of endothelial reactivity in the pulmonary circulation. Based on this assumption, one may hypothesize that endothelial dysfunction of pulmonary arteries would be associated with impaired airway function. Accordingly, Peinado and colleagues showed that maximal relaxation of pulmonary arterial rings induced by acetylcholine is correlated with the $\mathrm{FEV}_{1} / \mathrm{FVC}$ ratio of COPD patients [4]. Inasmuch as endothelial dysfunction is associated with dysregulated nitric oxide (NO) metabolism, we speculated that NO-mediated bronchodilation would also be impaired. We therefore conducted this study to assess whether endothelial dysfunction of pulmonary arteries was associated with modifications of the level of resting tone of isolated airways and their cGMP-mediated dilation. Both parameters are NOdependent, and the former has previously been suggested to be associated with the level of airflow limitation [5]. 


\section{Material and Methods}

\subsection{Patients}

Consecutive patients referred for lung surgical procedure (lobectomy or pneumonectomy for lung tumour) were eligible. Since impaired flow-mediated systemic dilation has been associated with low pulmonary function in former smokers, only ex-smokers were included (>15 Pack-Year). Based on the post-bronchodilator value of pre-operative pulmonary function test, patients were classified according to GOLD criteria [6]. All patients were informed of these biological experiments (bioethics' law of august 2004). This study was approved by our Institutional Review Board.

\subsection{Pharmacological studies}

Just after resection, segments of pulmonary arteries and bronchi were taken from an area as far as possible from the tumour and were dissected free of parenchyma. Arterial rings were evaluated immediately after dissection, whereas bronchial rings were placed in oxygenated Krebs's solution and stored overnight at $4^{\circ} \mathrm{C}$, as previously described $[5,7,8]$.

Intralobar arterial rings (inside diameter of 1.5-2 $\mathrm{mm}$ ) or bronchial rings (inside diameter 1-2 $\mathrm{mm}$ ) were suspended on tissue hooks in $5 \mathrm{ml}$ organ baths containing Krebs-Henseleit solution (NaCl, $119 \mathrm{mM}$; KCl, $5.4 \mathrm{mM}$; CaCl2, $2.5 \mathrm{mM}$; KH2PO4, $1.2 \mathrm{mM}$; MgSO4, $1.2 \mathrm{mM}$; NaHCO3, $25 \mathrm{mM}$; glucose, $11.7 \mathrm{mM}$ ), gassed with $95 \% \mathrm{O}_{2}: 5 \% \mathrm{CO}_{2}$ and maintained at $37^{\circ} \mathrm{C}$ ( $\mathrm{pH}$ 7.4). Each preparation was connected to a force displacement transducer (Statham UF-1) and isometric tension changes recorded in a computer (acquisition system: EMKA France, Bourre, France). All conditions were run in duplicate (when the duplicate experiments show discordant values, no result is given).

2.2.1. Arterial experiments: 
Endothelium-dependent relaxation was assessed by measuring the responses to acetylcholine (ACh, Pharmacie Centrale des Hôpitaux, Paris, France) in vessels preconstricted with Lphenylephrine dichloride $\left(10^{-5} \mathrm{M}\right)$. Relaxation to ACh was expressed as a percentage of relaxation of phenylephrine induced tone. The absence of ACh-induced dilation or even a contractile response defined endothelial dysfunction, which constitutes a stringent definition that is based on the upper normal limit of the response in non smokers with normal lung function in our laboratory. accordingly to previous experiments done in an historical group of non-smokers. We previously demonstrated that the decrease in vascular reactivity was not due to endothelial damage during manipulations [7].

\subsubsection{Bronchial experiments:}

After the initial loading of $2.5 \mathrm{~g}$ and subsequent equilibrium period, an initial resting tension (RT1) was obtained, bronchial viability was assessed using $10^{-3} \mathrm{M}$ ACh. Then a new resting tension (RT2) was obtained, and a dose response curve to zaprinast $\left(10^{-8}\right.$ to $\left.10^{-5} \mathrm{M}\right)$ was conducted. At the end of the experiment, after an equilibrium period to resting tension, maximal dilation $\left(10^{-3} \mathrm{M}\right.$ theophylline) was assessed, as previously described [9]. The absence of epithelial damage has also been checked in preliminary experiments [5]. Results were expressed as raw values (g) or percentage of theophylline-induced relaxation, as specified. The investigators performing bronchial experiments were blinded for the results of vascular experiments.

\subsection{Statistical analyses}

Results are expressed as median [interquartile range]. Data were analyzed using Statview 5.0 (SAS Institute, Inc, North Carolina). For intergroup comparisons, categorical variables were compared using the chi-squared test or Fisher's exact test, and continuous variables were compared using the Mann-Whitney $\mathrm{U}$ test or Kruskal Wallis test as appropriate. For 
intragroup comparisons, continuous variables were compared using the Wilcoxon paired test.

The Spearman's rank correlation coefficient was used to examine possible correlation between two variables. A $P$ value less than 0.05 was considered as significant.

\section{Results}

The clinical and functional characteristics of the 20 patients who were included are described in table 1. The characteristics of patients with and without dysfunction were similar. The figure 1 shows acetylcholine response of preconstricted arterial rings in patients with $(n=5)$ and without endothelial dysfunction $(n=15)$.

The degree of airflow limitation was significantly correlated with the level of initial resting tension $(\mathrm{RT} 1)(\mathrm{Rho}=-0.49 ; \mathrm{p}=0.032)$, and tended to be correlated with theophylline-induced maximal dilation $(\mathrm{Rho}=-0.38, \mathrm{p}=0.096)$.

The response to acetylcholine (constriction to dilation) of arterial rings was correlated with the degree of zaprinast-induced bronchodilation (figure 2), and tended to be correlated with the $\mathrm{FEV}_{1} / \mathrm{FVC}$ ratio (with $\mathrm{ACh} 10^{-5} \mathrm{M}, \mathrm{Rho}=0.37, \mathrm{p}=0.11$ ).

The figure 3 shows that patients with endothelial dysfunction $(n=5)$, as compared to those without dysfunction $(n=15)$, were characterized by a higher level of resting tone after acetylcholine-induced contraction (RT2) and higher levels of tension under each single concentration of zaprinast (figure 3, upper panel). Since the level of RT2 was significantly different between the two groups of patients, their response to zaprinast was further evaluated as percentage of theophylline-induced maximal dilation (similar for the two groups). The impaired response to zaprinast is further confirmed (figure 3, lower panel), suggesting an impairment of cGMP-mediated dilation in COPD patients with endothelial dysfunction. 


\section{Discussion}

\subsection{Background}

It has been shown that an impairment of flow-mediated dilation in systemic circulation occurs early in COPD, and is associated with airflow limitation, independently of smoking history, further suggesting a link between vascular and bronchial functions [1]. We suggest that in former smokers, endothelial dysfunction of pulmonary arteries is associated with impairment of both spontaneous resting tone and cGMP-mediated dilation of airways, establishing a biological link between pulmonary arterial and bronchial functions. To our best knowledge, comparison of arterial and bronchial pharmacological functions obtained from the same lung sample has never been made, and the description of dysfunction of pulmonary arteries has been assessed in a very limited number of studies $[4,10,11]$. A recent pulmonary perspective supported by the National Heart, Lung, and Blood Institute stated that there is a need for methods linking in vitro observations to in vivo disease state with regard to airway smooth muscle function [12]. Along this line we show an inverse relationship between the level of resting tone and $\mathrm{FEV}_{1}$, which is consistent with the fact that increased smooth muscle tone may contribute to airflow limitation in COPD, as previously suggested [5, 13, 14]. In our limited series of patients, airflow limitation was similar whether or not endothelial dysfunction was present. Several factors have been shown to contribute to systemic endothelial dysfunction, and our study was not powered to describe clinical and functional factors associated with pulmonary endothelial dysfunction.

\subsection{Endothelial dysfunction}


There is no consensual definition of pulmonary endothelial dysfunction, but we do think that the absence of acetylcholine-induced dilation or even contractile response constitutes a drastic definition. We observed that one quarter of our COPD patients displayed pulmonary endothelial dysfunction, which is in agreement with our subsequent results observed in a larger series [8]. No data are available in the literature for further comparison, but a $\sim 30 \%$ incidence of pulmonary hypertension in COPD patients has been reported [10]. In the study of Peinado and colleagues in mild COPD patients (mean \pm SD: $24.9 \pm 22.9 \%$ ), the dilator response to acetylcholine was diminished as compared to non smokers $(40.1 \pm 22.0 \%)$, without reaching statistical significance. The standard deviations of their results suggest that some COPD patients depicted a constrictor response to acetylcholine while almost all non smokers have a vasodilator response. Obviously, our results need to be confirmed in a larger sample of patients due to the restricted size of our sample with endothelial dysfunction.

\subsection{Bronchial dysfunction}

The nil to moderate degree of cGMP-mediated bronchial dilation that is evidenced is consistent with the results of other investigators [15-17], emphasising the confounding effect of underlying pathology (such as endothelial dysfunction) and the modest contribution of cGMP-mediated dilation in airways. The presence of a systemic endothelial dysfunction suggests an impairment of NO-mediated relaxation in COPD. Our results further argue for a generalized impairment of NO-dependent functions, affecting both vascular and bronchial lung compartments. Airway blood flow reactivity has also been shown to be impaired in exsmokers [18]. Mullershausen and colleagues have demonstrated a similar mechanism of desensitization of NO/cGMP signaling in smooth muscle of both aorta and bronchi of rats, involving phosphodiesterase (PDE) 5 activation [19], giving insight into the underlying 
mechanisms of generalized endothelial dysfunction. An increased expression of PDE 5 in models of pulmonary hypertension has been demonstrated [20].

Figure 3 shows that resting tension after ACh was higher in the group with endothelial dysfunction that could already be related to an impaired relaxation after contraction. The bronchial relaxation induced by the nonselective phosphodiesterase (PDE) inhibitor (theophylline) was similar whatever the presence or absence of impaired cGMP-dependent relaxation (see Figure 3). It first suggests that cAMP-dependent relaxation is preserved whatever the degree of impairment of cGMP-mediated relaxation. In human bronchial smooth muscle, the presence of PDE I, II, III, IV (cAMP specific) and V (cGMP specific) have been identified $[16,21,22]$. One should have expected that theophylline-induced relaxation would be lower in presence of an impairment of cGMP relaxation. Since theophylline, in addition to its PDE inhibitory activity, is an antagonist at adenosine receptors, blockade of adenosine activity has been proposed as a possible mechanism for theophylline's effects. Accordingly, Ethier and Madison have shown that, in addition to its well-established indirect effects on smooth muscle cells, adenosine also has direct effects on contractile signalling pathways since it mobilizes intracellular calcium stores [23]. This may explain why theophylline has a very potent bronchodilating effects ex vivo using a high concentration.

\subsection{Clinical perspectives}

Establishing a formal relationship between pulmonary vascular and bronchial functions is an important issue. We further suggest that NO-related dysfunction may participate in this link. Whether pulmonary endothelial dysfunction is associated with COPD morbidity warrants further studies. But we recently evidenced a frequent endothelial dysfunction of ex vivo pulmonary arteries of patients suffering from cystic fibrosis (that was associated with pulmonary hypertension), and we further demonstrated that criteria of mild pulmonary 
vascular disease were evidenced in some patients with cystic fibrosis that participated in exercise limitation [24].

Finally, it will deserve assessing the effects of statins on bronchial functions because reductions in COPD morbidity and mortality, and improvements in lung function, have been attributed to statin use. Insights into cellular mechanisms indicate that statins promote vasorelaxation partly by upregulating the expression of endothelial NO synthase [25].

\subsection{Conclusion}

This is the first study suggesting that endothelial dysfunction of pulmonary arteries is associated with increased resting tone and impaired cGMP-mediated dilation of airways in former smokers, suggesting common underlying mechanisms of pulmonary arterial and bronchial dysfunctions. 


\section{Acknowledgments}

Mehdi Oualha was supported by a grant from the Fondation pour la Recherche Médicale, Jean-François Boitiaux was supported by a grant from the Société de Pneumologie de Langue Française and Jean-Marc Tadié was supported by a grant shared by the Société de Pneumologie de Langue Française and the Société de Réanimation de Langue Française.

\section{Conflict of Interest}

The authors declare no conflict of interest. 


\section{References}

[1] Barr RG, Mesia-Vela S, Austin JH, Basner RC, Keller BM, Reeves AP, et al. Impaired flow-mediated dilation is associated with low pulmonary function and emphysema in exsmokers: the Emphysema and Cancer Action Project (EMCAP) Study. Am J Respir Crit Care Med. 2007;176:1200-7.

[2] McAllister DA, Maclay JD, Mills NL, Mair G, Miller J, Anderson D, et al. Arterial stiffness is independently associated with emphysema severity in patients with chronic obstructive pulmonary disease. Am J Respir Crit Care Med. 2007;176:1208-14.

[3] Mills NL, Miller JJ, Anand A, Robinson SD, Frazer GA, Anderson D, et al. Increased arterial stiffness in patients with chronic obstructive pulmonary disease; a mechanism for increased cardiovascular risk. Thorax. 2008;63:306-11.

[4] Peinado VI, Barbera JA, Ramirez J, Gomez FP, Roca J, Jover L, et al. Endothelial dysfunction in pulmonary arteries of patients with mild COPD. Am J Physiol. 1998;274:L908-13.

[5] Tadie JM, Henno P, Leroy I, Danel C, Naline E, Faisy C, et al. Role of nitric oxide synthase/arginase balance in bronchial reactivity in patients with chronic obstructive pulmonary disease. Am J Physiol Lung Cell Mol Physiol. 2008;294:L489-97.

[6] Pauwels RA, Buist AS, Calverley PM, Jenkins CR, Hurd SS. Global strategy for the diagnosis, management, and prevention of chronic obstructive pulmonary disease. NHLBI/WHO Global Initiative for Chronic Obstructive Lung Disease (GOLD) Workshop summary. Am J Respir Crit Care Med. 2001;163:1256-76.

[7] Henno P, Maurey C, Danel C, Bonnette P, Souilamas R, Stern M, et al. Pulmonary vascular dysfunction in end-stage cystic fibrosis: role of NF-kappaB and endothelin-1. Eur Respir J. 2009;34:1329-37. 
[8] Henno P, Boitiaux JF, Maurey C, Danel C, Barthes F, Delclaux C, et al. Tobacco smoking and pulmonary endothelial dysfunction. Eur Respir J. 2007;30 (suppl. 51):P3574 (abstract).

[9] Naline E, Qian Y, Advenier C, Raeburn D, Karlsson JA. Effects of RP 73401, a novel, potent and selective phosphodiesterase type 4 inhibitor, on contractility of human, isolated bronchial muscle. Br J Pharmacol. 1996;118:1939-44.

[10] Barbera JA, Peinado VI, Santos S. Pulmonary hypertension in chronic obstructive pulmonary disease. Eur Respir J. 2003;21:892-905.

[11] Dinh-Xuan AT, Higenbottam TW, Clelland CA, Pepke-Zaba J, Cremona G, Butt AY, et al. Impairment of endothelium-dependent pulmonary-artery relaxation in chronic obstructive lung disease. N Engl J Med. 1991;324:1539-47.

[12] Panettieri RA, Jr., Kotlikoff MI, Gerthoffer WT, Hershenson MB, Woodruff PG, Hall IP, et al. Airway smooth muscle in bronchial tone, inflammation, and remodeling: basic knowledge to clinical relevance. Am J Respir Crit Care Med. 2008;177:248-52.

[13] Lambert RK, Wiggs BR, Kuwano K, Hogg JC, Pare PD. Functional significance of increased airway smooth muscle in asthma and COPD. J Appl Physiol. 1993;74:2771-81.

[14] Opazo Saez AM, Seow CY, Pare PD. Peripheral airway smooth muscle mechanics in obstructive airways disease. Am J Respir Crit Care Med. 2000;161:910-7.

[15] Lagente V, Naline E, Guenon I, Corbel M, Boichot E, Burgaud JL, et al. A nitric oxidereleasing salbutamol elicits potent relaxant and anti-inflammatory activities. J Pharmacol Exp Ther. 2004;310:367-75.

[16] Rabe KF, Tenor H, Dent G, Schudt C, Liebig S, Magnussen H. Phosphodiesterase isozymes modulating inherent tone in human airways: identification and characterization. Am J Physiol. 1993;264:L458-64. 
[17] Torphy TJ, Undem BJ, Cieslinski LB, Luttmann MA, Reeves ML, Hay DW. Identification, characterization and functional role of phosphodiesterase isozymes in human airway smooth muscle. J Pharmacol Exp Ther. 1993;265:1213-23.

[18] Mendes ES, Campos MA, Wanner A. Airway blood flow reactivity in healthy smokers and in ex-smokers with or without COPD. Chest. 2006;129:893-8.

[19] Mullershausen F, Lange A, Mergia E, Friebe A, Koesling D. Desensitization of NO/cGMP signaling in smooth muscle: blood vessels versus airways. Mol Pharmacol. 2006;69:1969-74.

[20] Murray F, MacLean MR, Pyne NJ. Increased expression of the cGMP-inhibited cAMPspecific (PDE3) and cGMP binding cGMP-specific (PDE5) phosphodiesterases in models of pulmonary hypertension. Br J Pharmacol. 2002;137:1187-94.

[21] Barnes PJ. Cyclic nucleotides and phosphodiesterases and airway function. Eur Respir J. 1995;8:457-62.

[22] Rabe KF, Magnussen H, Dent G. Theophylline and selective PDE inhibitors as bronchodilators and smooth muscle relaxants. Eur Respir J. 1995;8:637-42.

[23] Ethier MF, Madison JM. Adenosine A1 receptors mediate mobilization of calcium in human bronchial smooth muscle cells. Am J Respir Cell Mol Biol. 2006;35:496-502.

[24] Hubert D, Aubourg F, Fauroux B, Trinquart L, Sermet I, Lenoir G, et al. Exhaled nitric oxide in cystic fibrosis: relationships with airway and lung vascular impairments. Eur Respir J. 2009;34:117-24.

[25] Tesfamariam B. The effects of HMG-CoA reductase inhibitors on endothelial function. Am J Cardiovasc Drugs. 2006;6:115-20. 


\section{Figure legends}

Figure 1: Acetylcholine-response of preconstricted arterial rings.

Patients were divided according to their response to acetylcholine: endothelial dysfunction (grey circles) is defined by a constrictor response (negative values), while the normal response (white circle) is defined by dilation (positive values). Errors bars are 95\% confidence interval. \# denotes a $P$ value $<0.05$, * denotes a $P$ value $<0.005$.

Figure 2: Relationship between acetylcholine-induced arterial and zaprinast-induced bronchial dilations.

Acetylcholine-induced dilation of arterial rings is expressed as percentage of the constrictor response to phenylephrine (PE), whereas zaprinast-induced dilation of bronchial rings is expressed as percentage of maximal response to theophylline (theo). An equivalent molar concentration $\left(10^{-5} \mathrm{M}\right)$ for both drugs is selected for the figure, but the relationship between zaprimast $\left(10^{-5} \mathrm{M}\right)$ response and $\mathrm{ACh}$ was of borderline significance for $\mathrm{ACh} 10^{-7} \mathrm{M}(\mathrm{p}=$ 0.057 ) and significant for $\mathrm{ACh} 10^{-6} \mathrm{M}$ to $10^{-4} \mathrm{M}(\mathrm{p}=0.022$, figure and $\mathrm{p}=0.024$, respectively). Grey circles are patients with endothelial dysfunction (negative acetylcholine-induced dilation $=$ constriction, $\mathrm{n}=5$ ), whereas white circles are patients without endothelial dysfunction $(n=15)$. 
Figure 3: Zaprinast-induced bronchodilation.

Patients are divided according the presence of endothelial dysfunction (grey bars, $n=5$ ) or its absence (white bars, $\mathrm{n}=15$ ). Box and whisker plots show median, $25^{\text {th }}$ and $75^{\text {th }}$ percentile and $10^{\text {th }}$ and $90^{\text {th }}$ percentile.

Upper panel: Levels of tension (g) according to the condition, initial resting tone (RT1), constrictor response to acetylcholine $\left(10^{-3} \mathrm{M}\right.$ Ach), resting tone after contraction (RT2), dose response to zaprinast $\left(10^{-8}\right.$ to $\left.10^{-5} \mathrm{M}\right)$, and maximal dilation induced by theophylline $\left(10^{-3} \mathrm{M}\right.$ theo). \# denotes a $P$ value $<0.05, *$ denotes a $P$ value $<0.01$.

Patients without endothelial dysfunction depicted a weak but highly significant dilator response to zaprinast as compared RT-2 level: $10^{-8} \mathrm{M}$ zaprinast, $\mathrm{p}=0.009 ; 10^{-7} \mathrm{M}, \mathrm{p}=0.020$; $10^{-6} \mathrm{M}, \mathrm{p}=0.011 ; 10^{-5} \mathrm{M}, \mathrm{p}=0.002$ (Wilcoxon paired test), whereas patients with dysfunction had no significant dilator response to zaprinast ( $p>0.05$ for all concentrations, Wilcoxon test).

Lower panel: Response to zaprinast expressed as percentage of maximal theo-induced dilation $\left(10^{-8}\right.$ to $\left.10^{-5} \mathrm{M}\right)$. A significant dilator response is evidenced in patients without endothelial dysfunction (trend for $10^{-7} \mathrm{M}$, significant for $10^{-5} \mathrm{M}$ ). 
Table 1. Characteristics of the patients.

\begin{tabular}{|c|c|c|c|}
\hline Characteristic & $\begin{array}{c}\text { Patients with ED } \\
\qquad n=5\end{array}$ & $\begin{array}{l}\text { Patients without ED } \\
\qquad n=15\end{array}$ & $P$ value \\
\hline Age, years & $61[51-66]$ & $64[58-70]$ & NS \\
\hline Sex ratio, Female/Male & $1 / 4$ & $2 / 13$ & NS \\
\hline Tobacco, Pack-years & 30 [26-60] & $50[21-65]$ & NS \\
\hline $\mathrm{FEV}_{1}, \%$ predicted & 78 [72-99] & 88 [75-99] & NS \\
\hline Smokers without COPD, $\mathrm{n}$ & 3 & 10 & NS \\
\hline GOLD class, $\mathrm{n}$ & & & NS \\
\hline Class I & & 2 & \\
\hline Class II & 0 & 3 & \\
\hline Preoperative chemotherapy, $n$ & 1 & 3 & NS \\
\hline
\end{tabular}

Results are expressed as median [interquartile range]

ED denotes endothelial dysfunction; NS denotes non significant

$\mathrm{FEV}_{1}$ denotes forced expiratory volume in one second (post-bronchodilator value) 


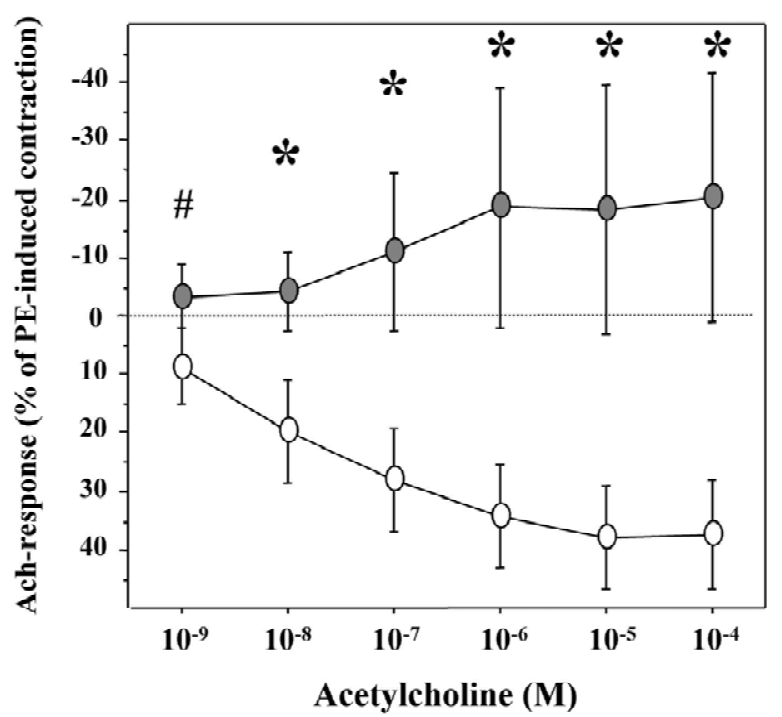




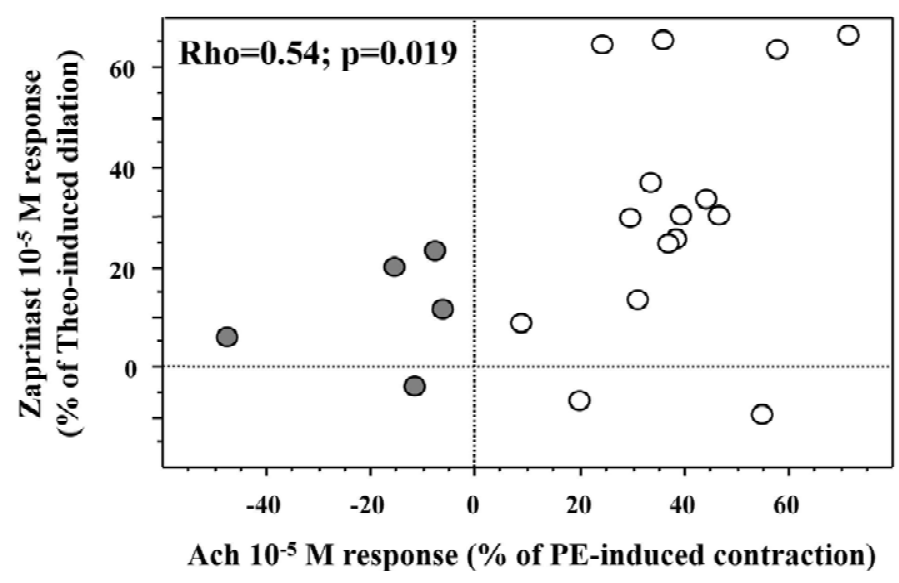



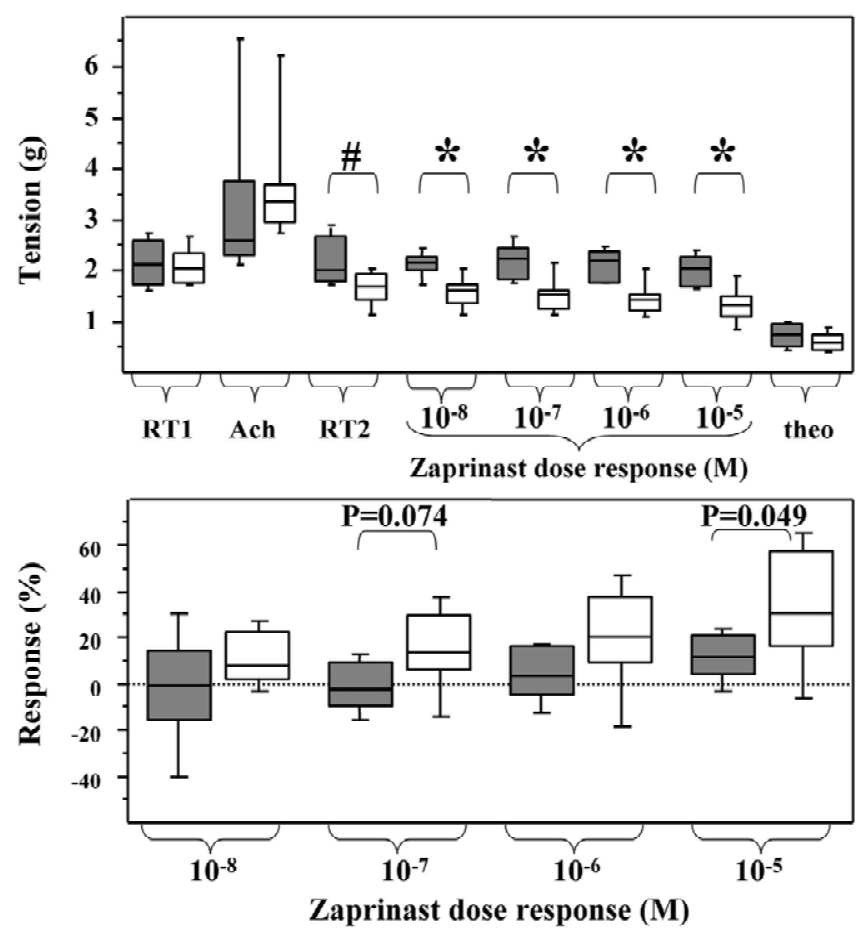


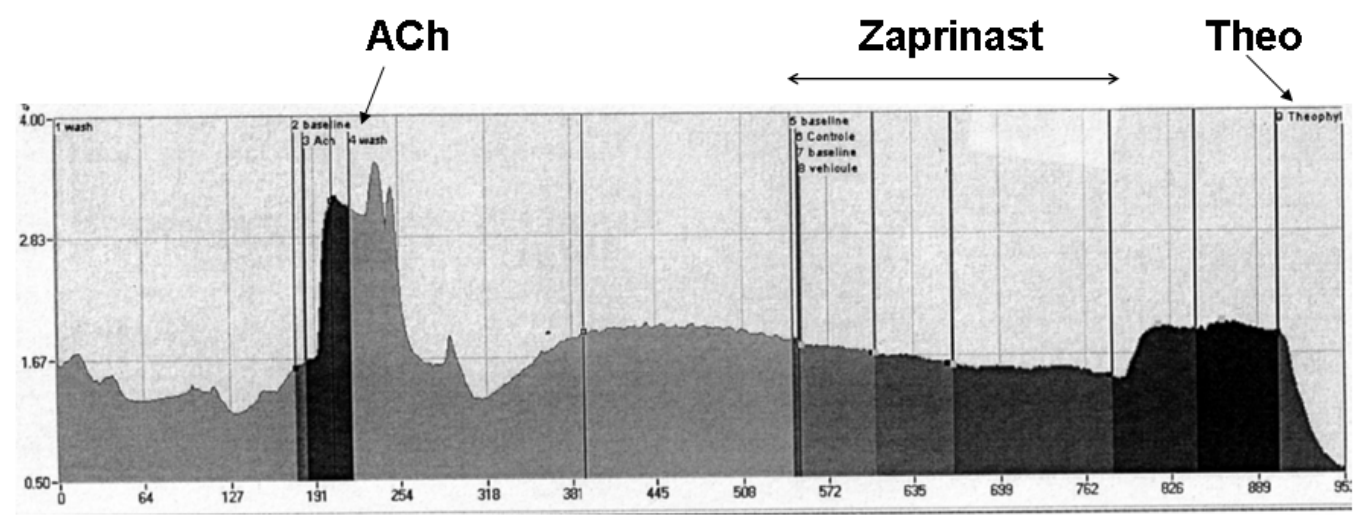

